\title{
LANTANA CAMARA: A POTENT INFLUENTIAL FACTOR IN IMPROVING THE GASTRIC MUCOSA OF WISTAR RATS RAVAGED BY ULCER
}

\author{
GABRIEL D. EDEM ${ }^{1}{ }^{*}$, KINGSLEY A. OKON ${ }^{1}$, SARAH I. ESSIEN $^{2}$, ENO-OBONG I. BASSEY $^{1}$ \\ ${ }^{I}$ Department of Anatomy, College Of Health Sciences, University of Uyo, Nigeria \\ ${ }^{2}$ Department of Chemical Pathology, Faculty Of Basic Clinical Sciences, University of Uyo, Nigeria \\ Corresponding author: profgabe4sure@ gmail.com
}

(Received, $20^{\text {th }}$ March 2020, Revised $8^{\text {th }}$ May 2021, Published $11^{\text {th }}$ May 2021)

\begin{abstract}
Over the years, traditional medicine has been used to treat various degrees and forms of ailment with significant positive therapeutic outcome. We designed this research to ascertain the use of Lantana camara as a potent factor in improving gastric ulcer caused by the administration of aspirin in Wistar rats. 250mg/kg of the extract was used to evaluate the anti-ulcer capacity of the plant extract. The omeprazole was used as a standard drug $(20 \mathrm{mg} / \mathrm{kg})$. It was found that the Gastric mucosa was significantly improved after the administration of $250 \mathrm{mg} / \mathrm{kg}$ of the extract after aspiri-induced ulcer. The present study justifies the traditional usage of this plant to treat the gastric ulcer.
\end{abstract}

Keywords: Gastric mucosa, Lantana camara, aspirin, omeprazole, ulcer

\section{Introduction}

Lantana camara is an important medicinal plant. The plant has been documented to posess antiinflammatory effect, anti-hyperglycemic tendency, anti-motility property and anti-fungal ability (Sanjeeb et al., 2012). Since the synthetic drugs used in the treatment and prevention of ulcer have a number of pitfalls such as gynecomastia and hyperplasia. Medicinal plants are effective in the treatment of human diseases, Lantana camara is one of such plants which have been used to cure human diseases (Atawodi, 2005). Gastric Ulcer is the disruption of the mucosal cytoarchitecture of the stomach particularly the epithelium, which may result in a perforation due to active inflammation. Symptoms of Gastric Ulcer include the following; upper abdominal pain that may improve with eating. Other symptoms includes belching, vomiting, weight loss and poor appetite (Snowden, 2008). Gastric ulcers are present in about $4 \%$ of the population (Snowden, 2008). About $10 \%$ of people developed gastric ulcer at some point in their life (Najm, 2011). Excessive gastric acid secretion is a factor in the pathogenesis of gastric ulcer disease (Adesanya et al., 2002). $H$. pylori is the etiologic factor in most patients with gastric ulcer disease and may predispose individuals to the development of gastric carcinoma. Helicobacter pylorus is a S-shaped gram negative bacterium which measures about 0.5 to $3 \mu \mathrm{m}$ in size. H.pylori colonizes in the human stomach. The method of H. pylori transmission is unclear, but seems to be person-to-person spread via a fecal-oral route (Ugochukwu et al., 2013). The use of nonsteroidal anti-inflammatory drugs has been linked with the development of gastric ulcers and complications such as gastrointestinal bleeding and perforation which are side effects can lead to death. NSAIDs initiate mucosal injury topically due to their acidic properties. This is done by diminishing the hydrophobicity of gastric mucus, endogenous gastric acid and pepsin thus injuring surface epithelium (Awofisayo et al., 2008). Systemic effects of NSAIDs appear to play a role through the reduced synthesis of mucosal prostaglandins (Akpotuzor et al., 2013).

Materials and methods

Handling of experimental animals

16 male Albino Wistar rats weighing between 170$200 \mathrm{~g}$ were obtained from the animal House of College of Health Sciences, University of Uyo, Nigeria. The animals were examined and weighed before the commencement of this experiment. They were kept in clean cages and given clean tap water $a d$ libitum.

\section{Preparation of drugs}

Aspirin (acetylsalicylic acid) was prepared by dissolving $300 \mathrm{mg}$ in $10 \mathrm{ml}$ of distilled water. Omeprazole was prepared by dissolving a single tablet $(20 \mathrm{mg})$ in $10 \mathrm{ml}$ of distilled water.

Collection of plant and identification

Lantana camara was obtained from Ekom Iman along Etinan-Uyo highway, Akwa Ibom State. The plant was identified at the Department of Botany and

[Citation: Edem, G.D., Okon, K.A., Essien, S.I., Bassey, E.O.I. (2021). Lantana camara: A potent influential factor in improving the gastric mucosa of wistar rats ravaged by ulcer. Biol. Clin. Sci. Res. J., 2021: 66. doi: https://doi.org/10.54112/bcsrj.v2021i1.66] 
Ecological studies, University Of Uyo with the Herbarium number: UUH 4023(Etinan).

\section{Plant extraction}

Extraction of the leaves of Lantana camara was done in the Department of Biochemistry, College of Health Sciences, University of Uyo.

\section{Experimental Protocol}

The animals were divided into 4 groups with 4 animals each.

Group 1 was given distilled water orally for 14 days Group 2 was given $300 \mathrm{mg} / \mathrm{kg}$ of aspirin dissolved in water and given intra-peritoneally as a single dose. Group 3 was given $300 \mathrm{mg} / \mathrm{kg}$ of aspirin dissolved in water and given intra-peritoneally plus $250 \mathrm{mg} / \mathrm{kg}$ of ethanolic extract of Lantana camara administered orally, 6 hours after ulcer induction for a period of 14 days.

Group 4 was given $300 \mathrm{mg} / \mathrm{kg}$ of aspirin dissolved in water and given intra-peritoneally plus

$20 \mathrm{mg} / \mathrm{kg}$ of omeprazole administered orally, 6 hours after ulcer induction for a period of 14 days.

\section{Ulcer Induction}

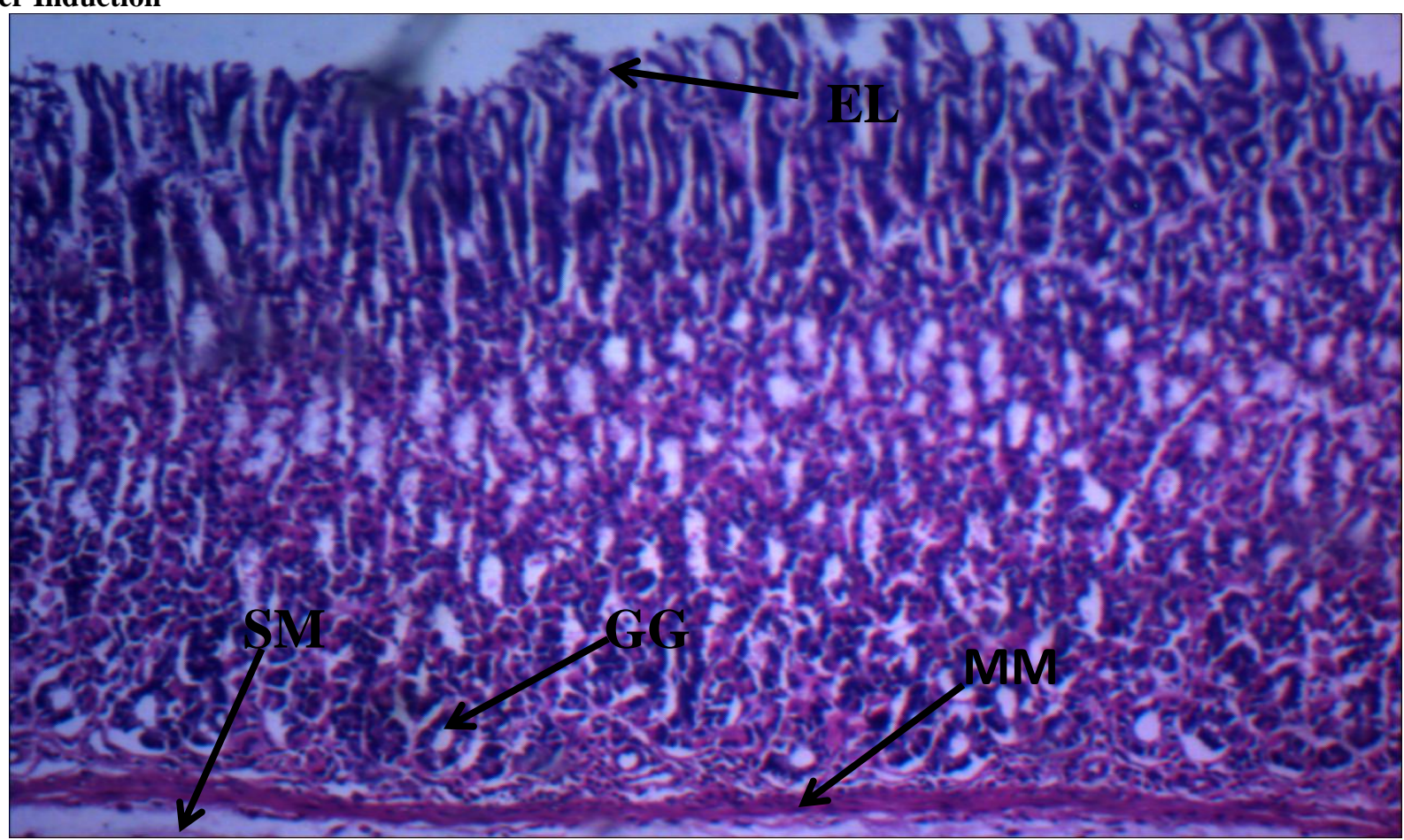

Figure 1: Photomicrograph of control group showing accurate epithelial $\operatorname{lining}(\mathbf{E L})$, muscularis mucosa (MM), submucosa $(\mathbf{S M})$ and Gastric glands(GG) : X10 magnification

[Citation: Edem, G.D., Okon, K.A., Essien, S.I., Bassey, E.O.I. (2021). Lantana camara: A potent influential factor in improving the gastric mucosa of wistar rats ravaged by ulcer. Biol. Clin. Sci. Res. J., 2021: 66. doi: https://doi.org/10.54112/bcsrj.v2021i1.66] 


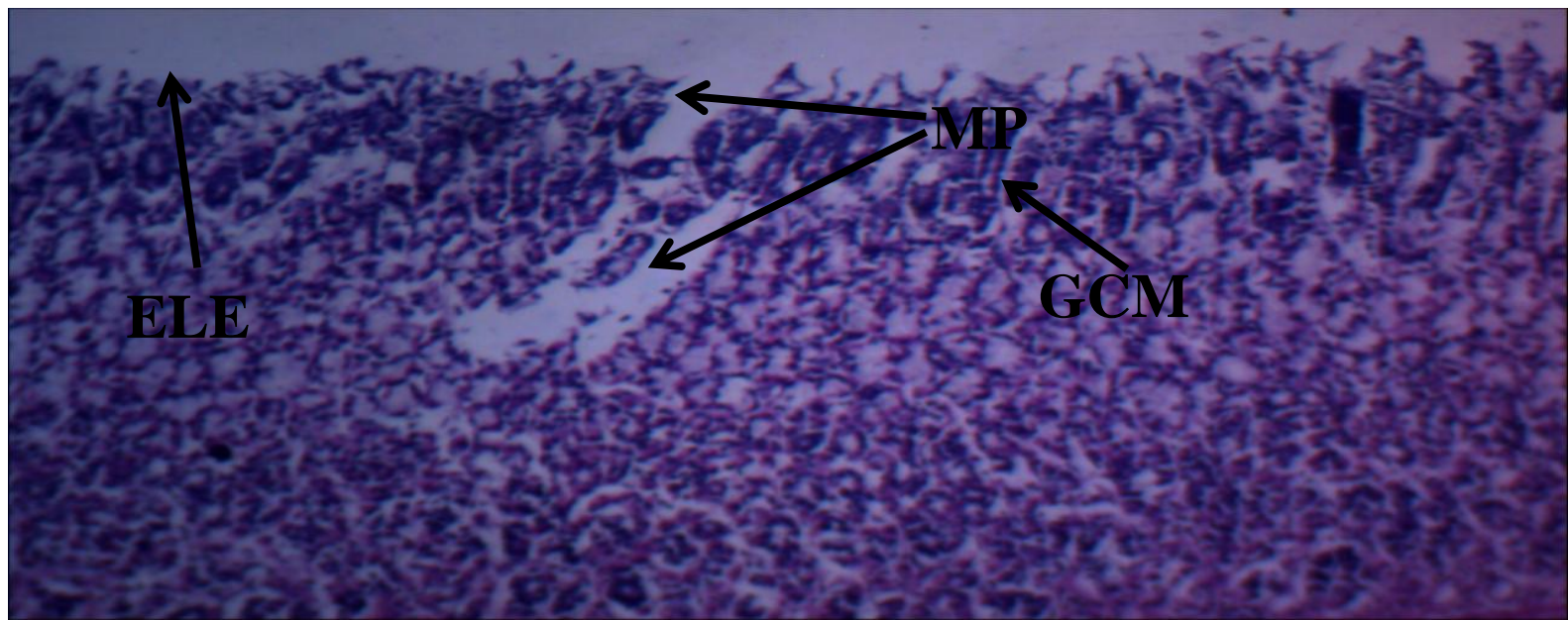

Figure II: Photomicrograph of group 2 administered with $300 \mathrm{mg} / \mathrm{kg}$ of aspirin showing mucosal perforations (MP), gastric cell metaplasia (GCM) and epithelial lining erosion (ELE) : X10 magnification.

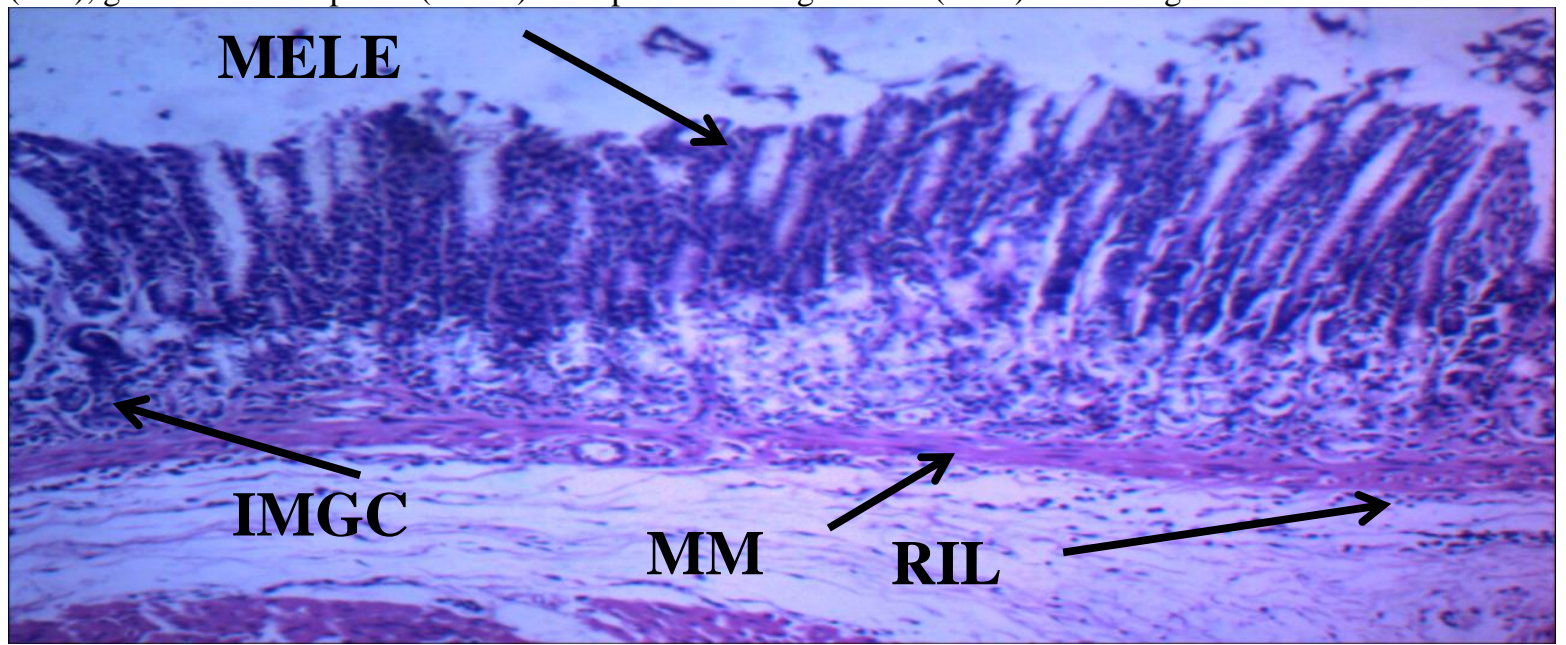

Figure III: Photomicrograph of group 3 administered with $300 \mathrm{mg} / \mathrm{kg}$ of aspirin and $250 \mathrm{mg} / \mathrm{kg}$ of Lantana camara showing mild epithelial lining erosion (MELE)), improved metaplastic gastric cell (IMGC), reduced infiltration of leucocytes (RIL) and muscularis mucosa (MM): X10 magnification.

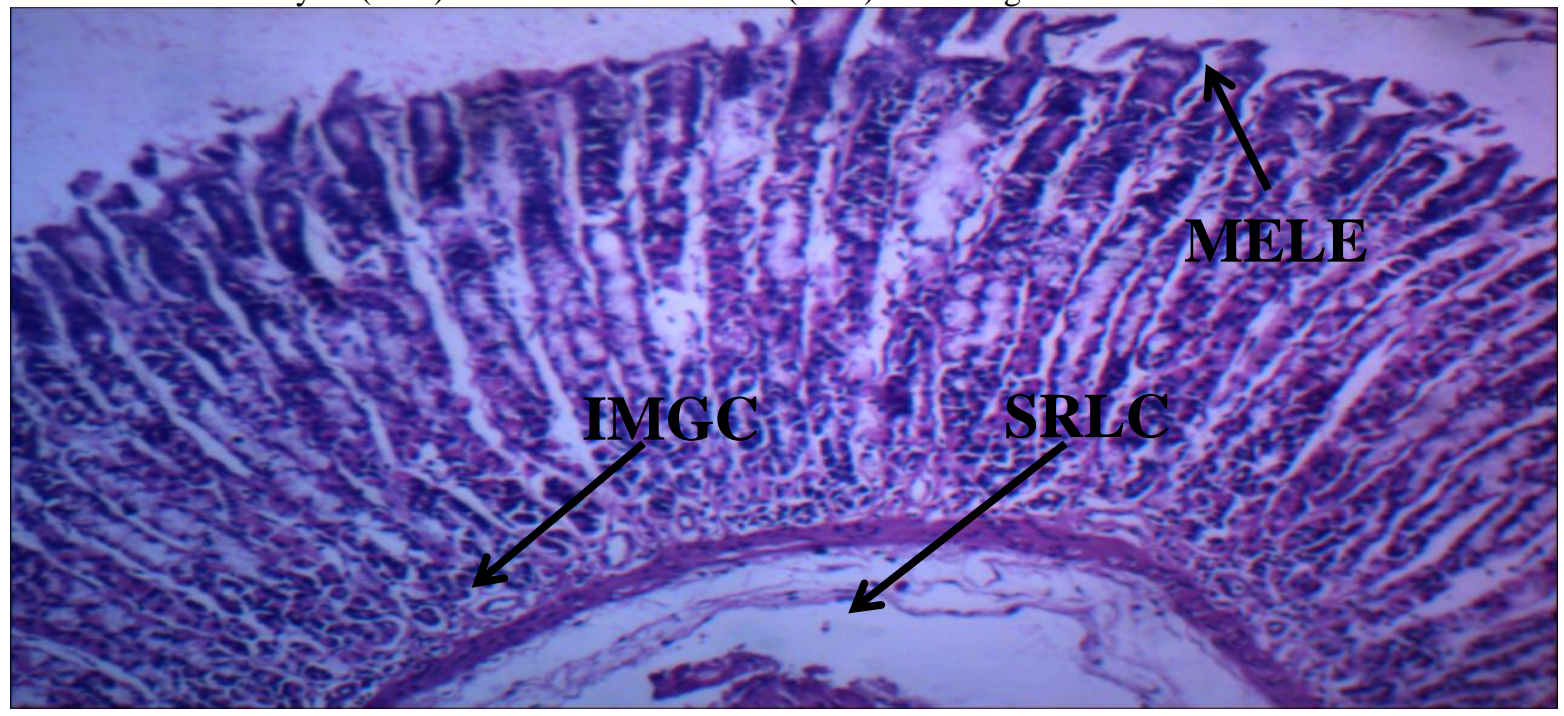

[Citation: Edem, G.D., Okon, K.A., Essien, S.I., Bassey, E.O.I. (2021). Lantana camara: A potent influential factor in improving the gastric mucosa of wistar rats ravaged by ulcer. Biol. Clin. Sci. Res. J., 2021: 66. doi: https://doi.org/10.54112/bcsrj.v2021i1.66] 
Figure IV: Photomicrograph of group 4 administered with $300 \mathrm{mg} / \mathrm{kg}$ of aspirin and $200 \mathrm{mg} / \mathrm{kg}$ of omeprazole showing mild epithelial lining erosion (MELE)), improved metaplastic gastric cell (IMGC) and significant reduction infiltration of leucocytic cell (SRLC): X10 magnification.

\section{Discussion}

The gastric mucosa consists of a surface epithelium that invaginates to various extents into the lamina propria forming gastric pits (Liuz and Jose, 2005). Viewing the epithelial surface of the stomach under the microscope showed numerous small irregular invaginations of the epithelial lining. An ulcer is a disruption of the mucosal integrity that leads to an excavation due to active inflammation. This corroborated the report from this research in the group administered with $300 \mathrm{mg} / \mathrm{kg}$ of aspirin which indicated severe mucosal perforation, epithelial lining and gastric cell metaplasia. The ulceration caused by any aggressive agent may be exacerbated by aggressive agents which may further result in additional gastric and duodenal ulcers (Liuz and Jose, 2005). Administration of Lantana extract indicated mild epithelial lining erosion and improved metaplastic gastric cell, this implies that certain processes that repair superficial damage of the gastric mucosa may be caused by several factors which play a very important role in the defense mechanism as well as adequate blood flow that promotes gastric physiological action (Liuz and Jose, 2005). This is also supported by the findings of Gabriel Edem et al., 2020 who noted that Lantana camara significantly ameliorates ulcer in male wistar rats by reducing gastric acidity, hydrogen ion concentration $(\mathrm{pH})$ and ulcer score.

\section{Ethical approval}

Ethical clearance to undertake this research was given by the ethical committee of the institution

\section{Conflict of interests}

Authors have declared that no competing interests exist.

\section{References}

Adesanya, A. A., Isaac, O., Kola O., \& RochaAfodu, J. T. (2002). Evaluation of a Locallymade Urease test for Detecting Helicobacter Pylori Infection. The Nigerian Postgraduate Medical Journal 9(1): 43-7.

Akpotuzor J. O., Udoh, A. E., \& Etukudo, M. H. (2013). Total Antioxidant Status and other Antioxidant Agent Levels in Children with P. Falciparum Infection in Calabar, Nigeria, International Journal of Biomedical Laboratory Science, 1(2): 35-39.

Atawodi, S. E. (2005). Antioxidant Potential of African Medicinal Plants. African Journal of Biotechnology 4 (2): 128-133.
Awofisayo, S., Oladojo, A., Iferi, I. I., \& Akpan E. E. (2008). The Pattern of Sale and Use of NonSteroidal Anti-Inflammatory Drugs in Rural and Urban Centres in Nigeria, Tropical Journal of Pharmaceutical Research, 7(3): 1013-1018.

Edem, G. D, Essien, S. I, Ekanem, A. U, Okon, K. A., \& Gabriel, S. S (2020). Lantana camara Ameliorates Gastric Ulcer in Aspirin-induced Ulcer in Wistar Rats. Drug Discovery, 14(33) $: 50-56$

Liuz, C. J., \& Jose, C. (2005). Basic Histology, Text and Atlas, $6^{\text {th }}$ edition, McGraw- Hill companies, $\mathrm{p} 288$.

Najm, W. I. (2011). Peptic Ulcer Disease. Primary Care: Clinics in Office Practice, 38, 383-394.

Sanjeeb K., Gaurav K., Loganathan K., \& Kokati V. B. (2012). A Review on Medicinal Properties of Lantana camara Linn, Research Journal of Pharmacy and Technology, 5(6): 711-715.

Snowden, F. M. (2008). Emerging and Reemerging Diseases: a Historical Perspective. Immunological Reviews, 25(1): 9-26.

Ugochukwu, S., Arukwe, U. I., \& Andonuaho, I. (2013). Preliminary Phytochemical Screening of Different Solvent Extracts of Stems Bark and Roots of Dennetia tripetala, Asian Journal of Plant Science and Research, 3(3):10-13.

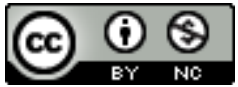

Open Access This article is licensed under a Creative Commons Attribution 4.0 International License, which permits use, sharing, adaptation, distribution and reproduction in any medium or format, as long as you give appropriate credit to the original author(s) and the source, provide a link to the Creative Commons licence, and indicate if changes were made. The images or other third party material in this article are included in the article's Creative Commons licence, unless indicated otherwise in a credit line to the material. If material is not included in the article's Creative Commons licence and your intended use is not permitted by statutory regulation or exceeds the permitted use, you will need to obtain permission directly from the copyright holder. To view a copy of this licence, visit http://creativecommons.org/licen ses/by/4.0/.

(C) The Author(s) 2021

[Citation: Edem, G.D., Okon, K.A., Essien, S.I., Bassey, E.O.I. (2021). Lantana camara: A potent influential factor in improving the gastric mucosa of wistar rats ravaged by ulcer. Biol. Clin. Sci. Res. J., 2021: 66. doi: https://doi.org/10.54112/bcsrj.v2021i1.66] 